\title{
Seminar on research results: the violation of the maxim of quantity produced by the undergraduate students at the english department STKIP YPUP Makassar
}

\author{
Fitriani* \\ ${ }^{1}$ English Department, STKIP YPUP Makassar, Indonesia \\ *Corresponding Author: fitrianimarsude@gmail.com | Phone Number: +6285395885687
}

\section{ARTICLE INFO \\ Received: 20-05-2021 \\ Received in revised: 20-06-2021 \\ Accepted: 18-07-2021 \\ Available online: 30-8-2021}

\section{KEYWORDS}

Cooperative Principle;

Maxim of quantity;

Research seminars;

Over-description;

\begin{abstract}
A B S T R A C T
This study aims at analyzing the violation of the maxim of quantity produced by undergraduate students in research seminar and the reason why they violate this kind of maxim. The researchers applied qualitative research design by using observation and in-depth interview. Four undergraduate students were the participants of this research recruiting using purposive random sampling. The results show that most of the participants violated the maxim of quantity by doing circumlocution (not to the point), providing more explanation, and talking too much. They considered that it was valuable for them to provide more information than needed to obtain the attention of the examiners. They assume that the more they speak the good outcome for their research seminar will be accomplished because having more explanation means they master their research content well.
\end{abstract}

\section{INTRODUCTION}

As usual social activities, communication activities can take place properly if all the participants in the conversation are actively involved in the communication. If one of the parties does not cooperate in the communication, the conversation cannot run smoothly. In order for the communication between the speaker and the hearer can run well, they must be able to cooperate. In addition, they must be aware that there is a rule in communication and this rule can be a guide to create meaningful communication. By considering the rule, misunderstanding can be avoided so that successful communication can be established. Therefore, cooperative principle, a theory proposed by (H. Paul Grice, 1975) can be a reference to make a good and successful communication, especially in the classroom. It is proposed a set of constraints on the interaction that he referred to as the Cooperative Principle, which states "Make your conversational contribution such as is required, at the stage at which it occurs, by the accepted purpose or direction of the talk exchange in which you are engaged". However, there is a phenomenon that most of the Indonesian students talk too much in conversation in which most of them violate the cooperative principle proposed by (Herbert P. Grice, 1970).
The cooperative principle has four guiding principles in communication called maxims which consist of quantity, quality, relation and manner. The maxim of quantity relates to the quantity of information provided. The maxim of quality refers to the truthfulness of the information provided. The maxim of relation relates to the relevancy of the information provided. The maxim of manner relates to the clarity of the information.

The above guiding principles can be applied in informal or formal situation. In terms of formal situation, it can be applied in results seminar. It is known that seminar on research results is one of the obligations for students that must be passed before heading to the thesis exam. Students are given the opportunity to carry out research seminars in order to get input from seminar participants. This activity is also expected to enrich the knowledge of the participants of the seminar on the topics presented by the students. However, this activity is not easy for the students. Many things became the barriers in the research seminars. The students are often nervous when they have to present their research results. They are fear of being asked by lecturers or examiners. In addition, fear of not being able to answer questions proposed by the examiners and the participants - 
is often the reason for the nervousness. This situation can influence the way they answer questions or the way they deliver their ideas. By facing this situation, the students may violate the four guiding principles in communication (maxims) proposed by Grice by producing ambiguous sentences do to the problems mentioned above. However, considering the Grice maxim help the students to overcome in producing unclear statements. These problems commonly occur at English department STKIP YPUP Makassar.

This study will focus on the maxim of quantity in which the researchers tried to find data where the students violate the maxim of quantity in the research seminars. In addition, this research will also find out the reason why the undergraduate students violate the maxim of quantity in the research result seminars. This represents an important topic to study because the cooperative principles theory proposed by Paul Grice governs the way people communicate but the fact shows that people sometimes break the proposed rules and they believe that they are still cooperate in the communication although they break the rule.

\section{LITERATURE REVIEW}

In recent decades, there has also been an increasing interest among psycholinguists in the psychological reality of Gricean 's rules about informativeness on linguistic comprehension (Anja Arts, Maes, Noordman, \& Jansen, 2011; Davies \& Katsos, 2013; Engelhardt, Bailey, \& Ferreira, 2006; Geurts \& Rubio-Fernández, 2015). Whether the violation of Gricean maxims will cause difficulty in the interpretation of sentences has been a hotly debated question. There have been numerous studies regarding this topic. Although some studies have shown that the provision of incomplete information has induced incomprehension (Davies \& Katsos, 2013; Engelhardt et al., 2006). Some have recorded no such drawbacks (Engelhardt et al., 2006), and some have also demonstrated the benefits of unnecessary information (Anja Arts et al., 2011; Geurts \& RubioFernández, 2015).

Several studies have also explored the Gricean Cooperative Principle and its maxims in language comprehension. The application of Grice maxims is crucial in mastering English skills such as listening comprehension. It is found that Grice's Conversational Implicature influences listening comprehension deeply, especially in understanding conversation. He suggests that non-English and English learners need to learn the necessary linguistics theories to guide their English listening comprehension. The pragmatic theory can help learners better understand the implicated meaning in English listening (Li, 2016).

Moreover, the Grice's maxims can be considered to create a meaningful interaction in the classroom interaction, a research entitled "Observance and NonObservance of Gricean Maxims in Instructional Context: An Analysis of EFL Classroom Interaction" has been conducted by (Safitri, Seken, MA, Putra, \& MA, 2014). The subjects were the teachers and students of the seventh and eighth grades of Gandhi Memorial International School (GMIS). The researchers collected the data through observation and interviews. The study showed that both teachers and students obeyed all of the Gricean maxims in a particular part of classroom teaching activities. This study also discovered that the teachers produced a high percentage of flouting the maxims. Teachers often preferred not blatantly delivering instructions in the classroom but expected the students to look for the implied meaning. Meanwhile, the students performed high percentages of violating the maxims and infringing the maxims. In this case, the students failed to observe the maxims because they were unable to speak clearly or lacked language ability in English.

In contrast to the above finding, it is found that the violation of the maxim of quantity does not directly affect reading comprehension. Ambiguous statements in the reading text that require at least one semantically compatible referent to be established do not instantly slow down comprehension. Violations of the Gricean maxims have an influence only after the referential analysis, based on the context of the referring term, has established applicable discourse referents (Fukumura \& van Gompel, 2017).

While supporting finding above that referential processing is more governed by the lexicosemantic representations of the referring expressions than by Gricean expectations, more recent work by $(\mathrm{Wu} \& \mathrm{Ma}$, 2020) reported that the mental model constructions of readers and the unique characteristics/processing patterns of the Chinese language may also affect referential processing.

In addition to the classroom situation, the Grice's maxims can be applied outside the classroom situations. A research entitled "The violating maxims of main characters in the hangover movie's script" has been employed by (Chairunnisa \& Natsir, 2014). The objectives of the study were to describe the violation of maxim, to describe the dominant type of maxim violation and to elaborate the reason for the maxim violation. The data were the dialogue of main characters in The Hangover movie. This research was conducted by using descriptive qualitative and limited on the main characters. The data analysis findings show that there are 22 violations of maxim of quality, two violation of maxim of quantity, nine violation of maxim of relation, and eight violation of maxim of manner. The reason of the violations are to give the lack of evidence, to lying to other speaker in hiding the truth, to save face the embarrassment, to present the strongest information, to 
represent what is in the speaker's mind, or to trick audience or listener for making a joke or not

A study entitled "A conversational implicature analysis in oscar Wilde's short story "happy prince" has been employed by (Risdianto, 2016). In this study, the researcher discusses conversational implicature in one of Oscar Wilde's short stories entitled -Happy Prince. The objectives of the study are to identify the implicature utterances conveyed by the characters in Oscar Wilde'sHappy Prince and to describe the implied meaning uttered by the characters in Oscar Wilde's -Happy Prince. It is found in the short story that there are some variation's meanings of the conversational implicature used in the short story which closely related to the conversational implicature; they are cooperative, politeness and ironical principle. In Oscar Wilde's short story-Happy Prince, there are six maxims of politeness principle, two maxims of cooperative principles and two maxims of ironical principles. Besides that, the reasons of the conversational implicature used in Oscar Wilde's short story-Happy Prince are to make us easily understand the dialogue in the short story conversations, and it is aimed at minimizing misunderstanding among the readers and literary critics.

Based on the previous research findings above, it can be concluded that there is a critical role of cooperative principle proposed by Grice in human communication both inside and outside the classroom situation. However, as discussed in the literature, there is a debate about the violation of the Grice maxims in relation to the language comprehension and the excessive or ambiguous information provided. In general, prior work is limited to a subset of reading comprehension, listening comprehension and literary works situation. In the present work, the researchers focus their research on the violation of the maxim of quantity produced by undergraduate students in the research result seminars at English department.

\section{METHODS}

\section{Research design}

The researcher applied the descriptive qualitative design. The researchers involved directly in this study by attending the results seminar online to gain the information about the violation of the maxim of quantity performed by students in the research results seminars. The purpose of qualitative research is to achieve a deep understanding of a particular phenomenon or process (Gay, Mills, \& Airasian, 2011).

\section{Participants}

There were some criteria for selecting the participants. The participants should be the eight semester. They should be scheduled to present their research results. The researcher took 4 undergraduate students to become the participants of this research, and these students can be representative to gain information about the violation of the maxim of quantity performed by undergraduate students in the research results seminars.

\section{Research Instruments}

Classroom observation using audio recorder was the main device in this study. In addition to an audio recorder, the researcher also conducted an interview. Therefore, there were two research instruments namely recording and interview. The first instrument was used to gain the data about the violation of the maxim of quantity in the research results seminars. The second instrument was used to obtain data about the reason why the undergraduate students violate the maxim of quantity in the research results seminars

\section{Procedures}

Before recording the classroom discussions, firstly the researcher came and observed the situation so that the researcher can design a planning about how to record the conversation to gain the relevant data. It also became the opportunity to interact and socialize with the participants and explained to them that the researchers would conduct a research and they were going to be observed as the participants of the research.

The data obtained from the classroom observation namely the transcription was analyzed based on (H. Paul Grice, 1975) theory. The researchers taken some violations performed by the students in the research seminars and put them as extracts. The researchers considered some criteria proposed by (H. Paul Grice, 1975) to determine the violations of the maxim of quantity performed by the students. They violate the maxim of quantity if the speaker does circumlocution or not to the point, if the speaker is uninformative, if the speaker talks too short, if the speaker talks too much if the speaker repeats certain words. In addition, data from the interview will be analyzed using (Huberman \& Miles, 2002) theory consisting of data reduction, data display, conclusion drawing and verification.

\section{RESULTS AND DISCUSSIONS}

This research aims at finding out the violation of the maxim of quantity produced by undergraduate students in the research result seminars at English department STKIP YPUP Makassar. To achieve this research objective, we did classroom observation and in-depth interview. The following table 1 is the data obtained from the classroom observation.

Table 1. Classroom observation on the violation of the maxim of quantity

\begin{tabular}{ccccc}
\hline \multirow{2}{*}{$\mathrm{P}$} & \multicolumn{4}{c}{ The Violation of the Maxim of Quantity } \\
\cline { 2 - 5 } The speaker & The & The & The speaker \\
does & speaker & speaker & repeats \\
circumlocution & talks too & talks too & certain \\
(not to the & short & much & words \\
\hline
\end{tabular}




\begin{tabular}{ccccc}
\hline & point) & & & \\
\hline P1 (I) & 3 & 1 & & 1 \\
\hline P2 & 2 & & 4 & 3 \\
(AC) & & & & \\
\hline P3 & 1 & 2 & 1 & 1 \\
(RP) & & & & \\
\hline P4 (R) & 2 & & 5 & 5 \\
\hline Total & 9 & 3 & & \\
\hline
\end{tabular}

The above table shows that P1(I) violate the maxim of quanitity 3 times by doing circomlocution (not to the point) in answering the examiners' questions. She also violated this maxim 1 time by talking to short. In addition, she repeated certain words 1 time. P2 (AC) did circomlocution two times, talked too much 4 times and repeated certain words 3 times. P3(RP) did circomlocution (not to the point), talked too much, and repeated certain words one time for each. P4(R) also did circomlocution (not to the point) 2 times. These data show that the maxim of quantity is violated in the reserch seminar.

\section{The speaker does circumlocution (not to the point)}

The data show that most of the students violated the maxim of quantity by doing circomlocution (not to the point). They tend to give more explanation before they answer the question from their examiners. The following extracts show how the students did circomlocution.

\section{Extract 1}

D: what kind of game? What is the different between this game and othehr game? apa bedanya dengan game yang lain

I: e.. According to Danmos that value of education game that is increases in language education. Paper plan game can increase skill in English. The difference is that this game is not familiar for the elementary school and the students do not play this game in the school like the other games which are familiar

\section{Extract 2}

Examiner: ya.. Why do you choose game as a strategy? (Noise)

P1(I): According to Auxial (2018) One of the methods that can be used is the use of Plane paper game. By using this game the teacher will be supported in the context of learning in the classroom (Silent)

Examiner: Jadi alasanmu memilih game itu apa? Tidak usah diperpanjang penjelasannya cukup alasannya saja

The extract 1 and 2 show that how P1(1) violated the maxim of quantitiy by doing circomlocution. In the extract 1 situation, the examiner asked about the reason why she choose peper plain game as the strategy to improve the students' vocabulary mastery. However, P1(I) was not directly answer her reason. She was trying to add an expert's opinion in order to support the reason why she choose the game. By doing this, the examiner reprimanded that P1(I) should dirctrly answer her reason choosing the game. She does not need to give more explanation before saying the reason.

\section{Extract 3}

Examiner: why ee why do you say that in pretest students have low score?

P1(I): based on the result of data analysis, the use of paper plain game as the strategy of teaching vocabulary, the students' mean score in pretest was 63.3 which is in average and the students mean score in posttest was six ee eighty six point sixteen which could be categorized in very good. so why the students in the pretest the students have low score because it is conducted before treatment.

\section{Extract 4}

Examiner: Tarsi bagaimana perhatiannya? How about their attention for you and for the material before and after? Are they have a good attention or not

P2(AC): pada pertemun yang pertama saya suruh mereka menulis sesuatu disitu jelas pada ranking score nya yang tertinggi hanya 61 pada tes yang terakhir setelah saya memberikan treatment, disitu sudah ada perubahan jadi bisa dibilang mereka punya good attention

The extract 3 and 4 show that P1(I) and P2(AC) violated the maxim of quantity by providing some explanations before answer the question from the examiner. In this situation, the examiner asked P1(I) the reason why in the pretest the students have low score. Instead of saying the reason directly, P1(I)described the results on pretest and posttest. She mentioned the reason after providing more explanation. What P1(I) did is same with what P2(AC) did in which P2(AC) did not directly answer the question from the examiners.

\section{Extract 5}

Examiner: Can you explain it?

P2 (AC): Thank you sir, yes

The extract 5 shows how P2(AC) violated the maxim of quantity. In this context, the examiner a very simple question "can you explain it?" which need yes or no answer. However P2(AC) said yes after saying thank you. In this case saying thank you before directly asnwer the question can be categorized as politeness. In this situation, P2(AC) was trying to show the politeness to the examiner.

\section{Extract 6}

Examiner: is it all the statement true? How many is true and lie?

P3(RP): yang pernyataannya mam?

Examiner: iya

P3(RP): eee karena itu hari saya bagi dalam 6 kelompok jadi tidak ada yang benar semua mam 
The extract 6 shows how P3(R) violated the maxim of quantity. In this situation the examiner asked the total number of students who have true or lie statements. P3(R) answered that there is no students who give the true statements. However before it, she explained that she divided the students into 6 groups in which this statement is not necessarily important to know.

\section{The speaker talks too short}

\section{Extract 7}

Examiner: My first question how does paper plain game increase students vocabulary? How this game increase students' vocabulary

P1(I): before I use paper plain game I did pretest and the score in the pretest is 63.3 and the I did treatment

\section{Extract 8}

Examiner: what is the difference between this game and the other game?

P3 (RP) : eee procedure nya sir

The extract 7 and 8 show how P1(I) violated the maxim of quantity by providing too short information in which the examiner's question need the detail explanation about how the paper plain game can increase the students' vocabulary. We can see in the extract 7 that P1 (I) did not give the detail explanation about the question "how". She just mentioned that she did pretest before using paper plain game as the treatment and she does not explain what is happening after treatment. What P1(I) did is also done by P3(RP) in which the maxim of quantity is violated. In this context, the examiner asked about the difference between paper plain game and other game. However, P3(RP) give a very short answer instead of explaining the difference in detail.

\section{Extract 9}

Examiner: ripa how can you know that this game can improve the vocabulary?

P3 (RP): Dari hasil post test nya mam

Examiner: Post testnya saja yang diliht?

P3 (RP): Iya mam

Examiner: untuk apaitu kerja pretest? Untuk apa itu kau lakukan pretest?

P3 (RP) untuk mengetahui kemampuan siswa mam sebelum dilakukan treatment

Examiner: So how did you know that there is an improvement after giving the treatment?

P3 (RP): from the result of the posttest mam after doing treatment

Examiner: dari hasil perbandingan antara pretest sama posttest

P3 (RP): iya maksudnya mam
Extract 8 shows how P3 (RP) violated the maxim of quantity. In this situation, the examiner wanted to know how the game can improve the students' vocabulary. However, P3(RP) did not provide a complete information. She just mentioned that we can see in the results of the posttest. In the next conversation, we can see that the examiner wanted to know more explanation by giving more questions and at the end the examiner explained that we can know that this game can increase from the different results between pretest and posttest. Then, P3(RP) agreed with the examiner's explanation by saying "that is what I mean mam".

\section{The speaker talks too much}

The extract 10 to 15 shows how the maxim of quantity is violated by talking too much then is required. The participats give some more exlpanantions after answering the questions form the examiners. According to the participants, providing more explanation is useful for them since they want to show to the examiners that they know more about their ressearch finding.

\section{Extract 10}

Examiner: is it a model?

P3 (AC): no sir it is process genre approach

\section{Extract 11}

Examiner: berapa kata yang diminta untuk mendeskripsikan presiden Jokowi?

P3 (AC): I just eee say that write the descriptive text abouth the object of Presiden

Examiner: tidak dibatasi? Artinya tidak ada minimal? AC: tidak ada sir, saya hanya menyuruh mereka menulis descriptive text

\section{Extract 12}

Examiner: jadi kalo bagaimana kalo mereka hanya mendeskripsikan hanya 1 kalimat? Bagaimana itu? P3 (AC): tidak mungkin mereka tidak mungkin menulis satu kalimat. yang pertama sir saya kasi masik pada konten nya kemudian bagaiamana organization language use and mechanics.

\section{Extract 13}

Examiner: did you describe it in your chapter IV in discussion?

P3 (AC): tidak mam, saya hanya membahas hasil kerja dari siswa skornya 


\section{Extract 14}

Examiner: mengenai perhatian siswa pada saat pertemuan 1 dan terakhir, apakah sama?

P3 (AC): ee beda mam pada pertemuan yang pertama dari segi pemahaman pasti mereka akan kebingungan perhatiannya pasti agak kurang tapi ketika saya mendatangi mereka dengn approach yang saya terapkan in ee jadi perhatiannya mereka itu agak berbeda dengan sebelumnya mereka mengikuti kelas lebih serius pada proses pembelajaran

\section{Extract 15}

Examiner: did you describe it in your chapter IV in discussion?

P3 (AC): tidak mam, saya hanya membahas hasil kerja dari siswa skornya

The following is the interview result which state that they need to provide more information than is required. The interview show that there are some reasons why the participants violate the maxim of quantity. The first reason is they want to give more explanation in order to make their statement clearer. The second is they need to provide more explanation because they want to make sure the examinners that they master the material in their research.

Interviewer: Kita orang Indonesia diberikan pertanyaan yes or no question tapi kadang kadang kita meresponnya tidak hanya menjawab yes or no tapi memberikan penjelasan lebih. Menurut anda ini sah saja dalam percakapan? Apakah ini dilakukan dengan tujuan supaya lawan bicara bisa lebih mengerti dengan memperoleh banyak informasi?

Participant: Menurut saya sah-sah saja. Apa lagi dalam ujian skripsi, menurut saya peserta yang dapat menjelaskan banyak hal menggambarkan bahwa mahasiswa tersebut menguasai materi skripsinya dengan baik. Akan tetapi ada juga pertanyaanpertanyaan yang memang benar-benar hanya membutuhkan iawaban va/tidak.

Interviewer: Kita orang Indonesia diberikan pertanyaan yes or no question tapi kadang kadang kita meresponnya tidak hanya menjawab yes or no tapi memberikan penjelasan lebih. Menurut anda ini sah saja dalam percakapan? Apakah ini dilakukan dengan tujuan supaya lawan bicara bisa lebih mengerti dengan memperoleh banyak informasi?

Participant: Menurut saya itu sah sah saja, karena terkadang kita butuh memberikan penjelasan lebih terkait kenapa kita menjawab yes or no , supaya jawaban yang kita berikan lebih jelas dan di mengerti.

\section{The speaker repeats certain words}

\section{Extract 18}

Examiner: Now, is there any advantages on your research of your strategy? Apa kelebihannya?

P1(I): eee... using this game ee using paper plain game e... yesterday student can active in the class and more enjoy for teaching English, students more fun and enjoy in english teaching

\section{Extract 19}

B: I'm sorry. What do you do in brainstorming? Apa yang kamu lakukan di brainstorming?

AC: I give the chance to describe a situation and write something in their paper sir. Jadi saya memeberikn kesempatan untuk dan ...

B: iya iya...

\section{Extract 20}

$\mathrm{N}$ : why do you choose that strategy?

AC: I think that it is an effective strategy for SMK nasional Makassar so I give this approach to the stdents how they wrtite descriptive text. So I ee apa terapkan strategi yang lain pada saat PPL mam itu tidak terlalu efektif karena ee dari segi pendekatan dengan mereka juga ya mungkin itu yang harus diperlukan dengan siswa disana. Begitu mam

N: ya...

Ac: saya memilih pendekatan ini mam karena berdasarkan pengalaman saya waktu KKLP saya gunakan strategi lain tidk terlalu efektif dalam pembelajaran jadi saya cob gunakan proses genre approach in bagaimana saya menghubungkan proses dan spesikfik genre yang saya gunakan untuk siswa disana

Extract 18 to 20 shows how the maxim of quantity is violated. In this situation, the participants answered the examiners' question directly but they repeated some words and sentences. It was happening because the internet connection at the moment is unstable. Therefore, they need to repeat some words so that the examiners know their answer clearly. The following is the interview why the participants repeat some words even sentences.

Interviewer: Apakah kita perlu mengulang beberapa pernyataan saat merespon pertanyaan dari penguji?

Participant: Menurut saya , iya apalagi kalau ujian yang di lakukan secara daring/online. 
Interviewer: Apakah kita perlu mengulang beberapa pernyataan saat merespon pertanyaan dari penguji?

Participant: Bisa saja ada pertanyaan dari penguji yang kurang jelas atau mungkin kita tidak mendengarnya dengan baik karena kebisingan atau suara penguji terlalu kecil karena ini dilakukan secara online.

\section{DISCUSSIONS}

There is a rule govern the conversarion proposed by (H. P. Grice, 1975) called cooperative principles and its maxims. The maxims of Grice make the basic statement that language understanding is motivated by a default assumption that an utterance should be optimally informative (Fukumura \& van Gompel, 2017).The data obtained from the observation show that most of the students violate the maxim of quanitity. They violated of this maxim in different forms namely. First, the speaker does circumlocution (not to the point). Second, the speaker talks too short. Third, the speaker talks too much. Fourth, the speaker repeats certain words.

The participants did circumlocution (not to the point) frequently. According to them, they need to provide more explanation because in research seminar, they are examined by the examiners. Providing more information means they master their thesis well and automatically they will get a good assessment. Therefore, they are trying to talk as much as they can. What they did is breaking the rule of conversation proposed by (H. P. Grice, 1975). However, breaking the rule does not mean that it is a mistake as long as the interlocutor understands what the speaker said. Speakers are supposed to include as much information as necessary for the identification of referents and no more, and it is assumed that listeners demand unambiguous but clear explanations (Engelhardt, Demiral, \& Ferreira, 2011). In addition, It is assumed that listeners are presented with over-descriptions frequently enough that when they hear them they are not disturbed (Engelhardt et al., 2011).

The result of this reserarch found that the undergraduate students violated the maxim of quantity by talking too much. They tend to provide extra information than is required. The undergraduate students here are ctegorized as adult learners. Many language learning studies have shown that adult speakers also provide redundant or unnecessary information (Belke, 2006; Deutsch \& Pechmann, 1982; Pechmann, 1989). On the contrary, typically, adult speakers are very good at adhering to the Quantity Maxim and ambiguous or underspecified reference expressions are rarely made(Engelhardt et al., 2006).

When producing referring expressions, speakers often provide extra information, which is contradictory with the Maxim of Quantity (H. P. Grice, 1975). In addition, several studies have shown that extra information is useful for understanding results (A. Arts, 2004; Anja Arts et al., 2011; Maes, Arts, \& Noordman, 2004). However, other studies have shown that additional data is detrimental to the efficiency of understanding (Engelhardt et al., 2006; Grodner \& Sedivy, 2011; Sedivy, 2003, 2007).

The result of the research also found that the participants violated the maxim of quantity by talking too short. This is happening because the students are less prepare in the research seminar so that they cannot provide more explanation as required by by the examiners. They feel nerveous so that what the examiners' asked is difficult to be answered by the students. when they are nerveous, they tend to provide under-description. However, enough information is required. The first is that speakers should include enough information for an object to be identified

The participants of this research also violated the maxim of quantity by repeating certain words or statement. It is may led to ambiguity of information. It is argued that ambiguity arises for the sake of communicative efficiency; ambiguous words are usually short and frequent and hence easy to produce or comprehend. Often the context provides sufficient cues about the intended meaning (Piantadosi, Tily, \& Gibson, 2012).

\section{CONCLUSIONS}

This study found that most of Indonesian undergraduate students violated the maxim of quantity by doing circumlocution (not to the point) and talking too much. They considered that providing more information than is required is useful for them to gain the examiners' attention. They believe the more they talk the good result from the examiner will be achieved because providing more explanation means that they do master their research content. What they did is inconsistent with the maxim of quantity. Therefore, it can be said that the maxim of quantity is not applied in the research result seminar. The future research wants to analyze the other maxims such as maxim of quality, maxim of relevant, and maxim of manner in the different context such as in the postgraduate level.

\section{Acknowledgement}

The authors would like to thanks to Simlitabmas for providing funds in conducting this research.

\section{Conflict of Interest}

The authors declare that they have no competing interests.

\section{REFERENCES}

Arts, A. (2004). Over specification in instructive texts (unpublished doctoral dissertation). Tilburg University.

Arts, Anja, Maes, A., Noordman, L. G., \& Jansen, C. (2011). Over specification in written instruction. Linguistics, 49(3), 555574. 
Belke, E. (2006). Visual determinants of preferred adjective order. Visual Cognition, 14(3), 261-294.

Chairunnisa, N., \& Natsir, M. (2014). The violating maxims of main characters in the hangover movie's script. Linguistica, 3(2). http://jurnal.unimed.ac.id/2012/index.php/jalu/article/view/12 29

Davies, C., \& Katsos, N. (2013). Are speakers and listeners 'only moderately Gricean'? An empirical response to Engelhardt et al.(2006). Journal of Pragmatics, 49(1), 78-106.

Deutsch, W., \& Pechmann, T. (1982). Social interaction and the development of definite descriptions. Cognition, 11(2), 159-184.

Engelhardt, P. E., Bailey, K. G., \& Ferreira, F. (2006). Do speakers and listeners observe the Gricean Maxim of Quantity? Journal of Memory and Language, 54(4), 554-573.

Engelhardt, P. E., Demiral, Ş. B., \& Ferreira, F. (2011). Overspecified referring expressions impair comprehension: An ERP study. Brain and Cognition, 77(2), 304-314.

Fukumura, K., \& van Gompel, R. P. G. (2017). How do violations of Gricean maxims affect reading? Journal of Memory and Language, 95, 1-18. doi: 10.1016/j.jml.2017.01.008

Gay, L. R., Mills, G. E., \& Airasian, P. W. (2011). Educational research: Competencies for analysis and applications. Pearson Higher Ed.

Geurts, B., \& Rubio-Fernández, P. (2015). Pragmatics and processing. Ratio, 28(4), 446-469.

Grice, H. P. (1975). Logic and conversation'in p. cole and j. morgan (eds.) syntax and semantics volume 3: Speech acts. Academic Press, New York.

Grice, H. Paul. (1975). Logic and conversation'in p. cole and $j$. morgan (eds.) syntax and semantics volume 3: Speech acts. Academic Press, New York.

Grice, Herbert P. (1970). Logic and conversation. na. Retrieved from https://edge.edx.org/asset-v1:Brown+CSCI2951K+2015_T2+type@asset+block/grice75.pdf

Grodner, D., \& Sedivy, J. C. (2011). 10 The Effect of SpeakerSpecific Information on Pragmatic Inferences. In The processing and acquisition of reference . 2327: 239-272. MIT Press.
Huberman, M., \& Miles, M. B. (2002). The qualitative researcher's companion. Sage.

Li, Q. (2016). Conversational Implicature in English Listening Comprehension Teaching. Theory and Practice in Language Studies, 6(10), 2044-2051. doi: $10.17507 /$ tpls.0610.22

Maes, A., Arts, A., \& Noordman, L. (2004). Reference management in instructive discourse. Discourse Processes, 37(2), 117144.

Pechmann, T. (1989). Incremental speech production and referential overspecification. Linguistics, 27(1), 89-110.

Piantadosi, S. T., Tily, H., \& Gibson, E. (2012). The communicative function of ambiguity in language. Cognition, 122(3), 280291.

Risdianto, F. (2016). A conversational implicature analysis in oscar wilde's short story "happy prince." Register Journal, $4(2)$.

http://ijims.iainsalatiga.ac.id/index.php/register/article/view/46

Safitri, L. M., Seken, P. D. I. K., MA, Putra, P. D. I. N. A. J., \& MA. (2014). Observance and Non-Observance of Gricean Maxims in Instructional Context: An Analysis of EFL Classroom Interaction. Jurnal Pendidikan Bahasa Inggris, 2(1). http://pasca.undiksha.ac.id/ejournal/index.php/jpbi/article/view/1434

Sedivy, J. C. (2003). Pragmatic versus form-based accounts of referential contrast: Evidence for effects of informativity expectations. Journal of Psycholinguistic Research, 32(1), 3-23.

Sedivy, J. C. (2007). Implicature during real time conversation: A view from language processing research. Philosophy Compass, 2(3), 475-496.

$\mathrm{Wu}, \mathrm{S} .$, \& Ma, Z. (2020). How is Chinese reading affected by underspecification and over-specification? Evidence from selfpaced reading experiments. Journal of Pragmatics, 155, 213-233. doi: 10.1016/j.pragma.2019.11.006 